\title{
Non-invasive methods of cardiac output measurement and their importance in everyday clinical practice: the current state of knowledge
}

\author{
Patrycja Stępniak ${ }^{1}$, Andrzej Cacko ${ }^{1,2}$, Agnieszka Kołodzińska ${ }^{1}$, Marcin Grabowski $^{1}$ \\ ${ }^{1} 1^{\text {st }}$ Department of Cardiology, Central Teaching Hospital, Medical University of Warsaw, Poland \\ ${ }^{2}$ Department of Medical Informatics and Telemedicine, Medical University of Warsaw
}

\begin{abstract}
Cardiac output is an important parameter in the evaluation of the patients' haemodynamic status which can be measured using a number of methods with varying degrees of invasiveness. These include invasive (such as pulmonary artery catheterization, transpulmonary thermodilution, lithium dilution), minimally invasive (catheter-based arterial pressure curve contour analysis, transoesophageal Doppler) and non-invasive (electrical bioimpedance, transthoracic echocardiography, measurement of exhaled $\mathrm{CO}_{2}$, continuous non-invasive blood pressure measurement) techniques. With advances in medicine, the role of non-invasive methods as an alternative to pulmonary artery catheterization continues to grow. The undoubted advantage of non-invasive methods is their safety for the patients and their wide availability. In contrast, invasive methods are characterized by greater measurement precision. It is up to the physician to choose the most appropriate haemodynamic monitoring method depending on the clinical situation. The aim of this article is to discuss non-invasive cardiac output measurement techniques and their application in everyday clinical practice.
\end{abstract}

Key words: cardiac output, non-invasive measurement, pulse wave analysis

Folia Cardiologica 2021; 16, 4: 237-241

\section{Introduction}

Measurement of cardiac output (CO) is one of the most common methods used for haemodynamic monitoring of patients in coronary and intensive care units. $\mathrm{CO}$ is also an important prognostic parameter in critically ill patients. CO may be measured using invasive or less invasive techniques. Although the experts still consider invasive methods the gold standard for haemodynamic evaluation, the role of non-invasive methods is increasing as they are safe and easily available tools for measuring $\mathrm{CO}$.

\section{Methods of $\mathrm{CO}$ measurement}

Cardiac output is blood volume pumped by the heart to the aorta over one minute, calculated as the product of stroke volume and heart rate. $\mathrm{CO}$ is one of key parameters in the evaluation of cardiac function and is of a fundamental importance in the diagnosis, treatment, and evaluation of prognosis in cardiovascular disease [1]. Optimal haemodynamic conditions allow maintaining adequate tissue oxygenation and homeostasis, which reduces the rate of complications, particularly in the periprocedural period. The importance of evaluating $\mathrm{CO}$ as summarized in the European Society of Cardiology (ESC) guidelines is shown in Table 1 [2-4].

Cardiac output is related to its four major determinants: heart rate, contractility, preload, and afterload [5]. The optimal choice of the haemodynamic monitoring method is determined individually [6]. Understanding of the measurement principles and indications for individual currently available $\mathrm{CO}$ measurement methods is of key importance.

Address for correspondence: Patrycja Stępniak MD, I Katedra i Klinika Kardiologii, Warszawski Uniwersytet Medyczny, ul. Banacha 1a, 02-097 Warszawa, Poland, phone +48 2259919 58, e-mail: patrycja_st@onet.pl

This article is available in open access under Creative Common Attribution-Non-Commercial-No Derivatives 4.0 International (CC BY-NC-ND 4.0) license, allowing to download articles and share them with others as long as they credit the authors and the publisher, but without permission to change them in any way or use them commercially. 
Table 1. The importance of evaluating cardiac output (CO) as summarized in the European Society of Cardiology (ESC) guidelines $[2-4]$

\begin{tabular}{|c|c|}
\hline Patient group & Description \\
\hline $\begin{array}{l}\text { Acute/chronic heart } \\
\text { failure [2] }\end{array}$ & $\begin{array}{l}\text { In the evaluation of heart failure } \\
\text { by stress echocardiography using } \\
\text { semi-supine cycle ergometer } \\
\text { Urgent resting echocardiography in } \\
\text { suspected acute heart failure, espe- } \\
\text { cially with haemodynamic instability } \\
\text { - reduced CO accompanied by evi- } \\
\text { dence of peripheral } \\
\text { hypoperfusion [2] }\end{array}$ \\
\hline $\begin{array}{l}\text { Hypertrophic cardio- } \\
\text { myopathy [3] }\end{array}$ & $\begin{array}{l}\text { Low } \mathrm{CO} \text { reserve favours inadequate } \\
\text { systolic blood pressure response to } \\
\text { exercise (blood pressure fall/no rise } \\
\text { in about } 1 / 3 \text { adults) [3] }\end{array}$ \\
\hline Pregnant women [4] & $\begin{array}{l}\text { Physiological increase in CO by } \\
40-50 \% \text { by about } 32 \text { weeks of ges- } \\
\text { tation - important when planning } \\
\text { delivery [4] }\end{array}$ \\
\hline
\end{tabular}

Table 2. Classification of the methods for measuring cardiac output in relation to their invasiveness

Invasive techniques
Pulmonary artery catheterization
Transpulmonary thermodilution
Lithium dilution
Minimally invasive techniques

Catheter-based arterial pressure contour analysis (using one catheter introduced into a peripheral vessel - radial artery)

Transoesophageal Doppler

Non-invasive techniques

Thoracic electrical bioimpedance (ICON, AESCULON monitors) Transthoracic echocardiography

Pulse wave contour analysis - continuous non-invasive blood pressure measurement devices (CNAP Monitor 500)

Exhaled carbon dioxide measurement (NICO monitors)

CNAP - continuous noninvasive blood pressure monitoring; NICO - noninvasive cardiac output

Regarding the degree of invasiveness, the techniques used may be divided into [6] (Table 2):

- invasive methods;

- minimally invasive methods;

- non-invasive methods.

\section{Non-invasive methods of $\mathrm{CO}$ measurement}

The major advantage of non-invasive techniques is their safety. Compared to the classical direct measurement by pulmonary artery catheterization, they are not associated

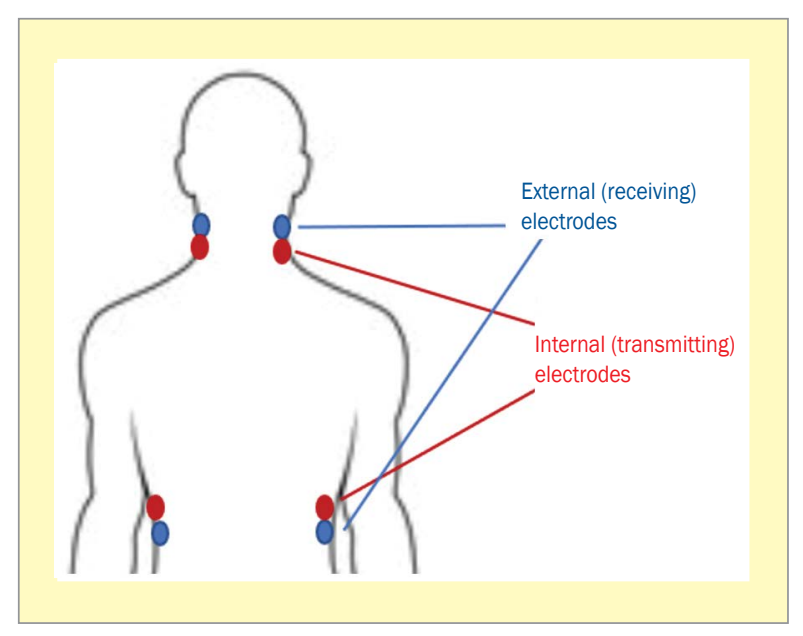

Figure 1. Electrode placing for bioimpedance measurements

with life-threatening complications such as arrhythmias, damage to the pulmonary artery and other adjacent arteries, lung infarction, damage to cardiac valves, or pericardial effusion [7].

\section{Thoracic electrical bioimpedance}

Thoracic electrical bioimpedance (TEB) is a technique based on the assumption that chest impedance is related to the amount of fluid in the chest compartment. A number of systems based on this technique are currently available (ICON, AESCULON, and other monitors) [8]. The use of this measurement method in the clinical practice was first reported in 1966 [9], and then in 1986 [10]. It is assumed that the maximum change in chest impedance is related to the peak aortic flow, the latter coinciding with an increase in chest conductance $[6,11]$ (Figure 1). Chest bioimpedance is thus dependent on the cardiac cycle phase (it decreases during ventricular systole and increases during diastole). This is related, among others, to the fact that during ventricular systole, erythrocytes are more aligned, resulting in a decreased impedance against the running current [11]. Technically, the method involves placing 8 leads on the patient's body. Four of them are the transmitting electrodes, which are the source of a high frequency, low intensity current, and the other four are receiver electrodes which record the electrocardiographic signal and voltage changes. The electrodes are placed in pairs consisting of one transmitting electrode and one receiving electrode. Two pairs are placed on the patient's neck on both sides, and the other two on the chest in the midaxillary line at the level of the xyphoid process (Figure 1). As according to the laws of physics changes in voltage and impedance are directly proportional to each other, these measurements allow assessment of chest bioimpedance, and with the use of dedicated algorithms, not only haemodynamic parameters such as stroke volume and cardiac output can be calculated 
[13] but also tissue oxygenation and cardiac contractility. Of note, however, measurements using this technique may interfere with other devices emitting the electromagnetic field and may be affected by these devices. Thus, use of this method is not recommended in patients with an implanted cardioverter-defibrillator. It is also not recommended in individuals with metal implants and pregnant women. It should be also noted that implanted cardiac electrotherapy devices may also provide information about chest impedance, and it was shown to be a predictor of heart failure exacerbations. In these settings, however, changes in chest impedance are due to a different mechanism, i.e., extracardiac fluid accumulation. Thus, impedance measurements should be interpreted as follows: the more fluid between the device and the lead, the lower the impedance [14].

\section{Exhaled carbon dioxide measurement}

The assumptions underlying this technique were first described by Adolph Fick who showed that the whole oxygen volume taken up in the lungs is transferred to the blood. Based on this assumption, cardiac output may be calculated as the ratio of oxygen consumption to the arteriovenous oxygen difference [15]. With further advances, new iterations were developed using various substitutes for oxygen. One of these methods is based on the modified Fick principle for carbon dioxide $\left(\mathrm{CO}_{2}\right)$ or the relation between exhaled $\mathrm{CO}_{2}$ and the amount of blood pumped through the heart.

The modified Fick equation for $\mathrm{CO}_{2}$ is as follows: $\mathrm{CO}=\mathrm{VCO}_{2} /\left(\mathrm{CpaCO}_{2}-\mathrm{CsaCO}_{2}\right)$,

where $\mathrm{CO}$ - cardiac output, $\mathrm{CpaCO}_{2}$ - partial $\mathrm{CO}_{2}$ tension in the pulmonary circulation, $\mathrm{CsaCO}_{2}-$ partial $\mathrm{CO}_{2}$ tension in the systemic circulation [16].

This technique is used in mechanically ventilated patients. One commercially available device is the Noninvasive Cardiac Output (NICO) system. The NICO monitor includes a $\mathrm{CO}_{2}$ sensor (absorbing infrared light), an airflow sensor, and pulse oximeter. However, limitations of this technique for evaluating $\mathrm{CO}$ should be noted. Studies show that use of NICO is not an optimal method in patients who breathe spontaneously. It was shown that in this patient group, measured $\mathrm{CO}$ values were significantly higher compared to the values obtained using the thermodilution method [15]. The validity of measurements using NICO in patients with lung damage has also been questioned.

\section{Noninvasive pulse wave contour analysis}

Arterial blood pressure is one of the basic parameters in the assessment of cardiovascular system function. Until recently, continuous beat-to-beat blood pressure monitoring required an invasive approach with the use of an intraarterial catheter [17]. Medical advances led to the development of several devices that allow noninvasive continuous blood pressure monitoring (CNAP 500, FinaPress, ClearSight monitors). These devices also allow a wider evaluation of haemodynamic parameters including $C O[8,18]$. The measurement technique used in these devices is based on the Penaz principle of pulse wave analysis, first described by this author in 1973. The method involves placing a sensor (finger cuff) on the index and middle finger to detect arterial blood flow. The cuff includes a sensor and a light-emitting diode. The change in light transmission through the finger (corresponding to a change in finger blood volume) is detected by the sensor. This information is transmitted to a pump that changes pressure in the cuff. In this way, the pressure measured in the cuff reflects blood pressure at each cardiac beat, following previous system calibration using the standard oscillometric method. Most commonly, the finger cuff is available in three sizes (small, medium, large), allowing adequate adjustment and reliable measurements, and is connected via a controller to a brachial blood pressure measurement cuff. The monitor displays a real-time dynamic blood pressure curve at a high resolution. Blood pressure measurements are continuously displayed on the monitor numerically or graphically [19]. The recorded blood pressure curve is analysed by the system (taking into account such variables as age, height, and body weight) and allows calculating $\mathrm{CO}$ using on a dedicated algorithm [6]. These monitors also allow calculating other haemodynamic parameters derived from the blood pressure curve, including stroke volume (SV), systemic vascular resistance (SVR), pulse pressure variation (PPV), stroke volume variation (SVV), stroke volume index (SVI), cardiac index (Cl), and systemic vascular resistance index (SVRI) [19]. Previous devices of this type were thought to be prone to measurement errors resulting from vasoactive changes. It is quite obvious that patients in intensive care units often receive large doses of vasoactive drugs which induce rapid changes in blood pressure but also affect peripheral arterial tone [17]. CNAP monitors were designed to eliminate these limitation by employing appropriate algorithms. The CNAP 500 monitor is an independent device that can be used on its own but it may also be connected to other patient monitoring systems [19], providing a more comprehensive picture of the patient's status beyond the cardiovascular system function. Use of this method is not recommended in patients with high peripheral resistance, patients in hypothermia, and with peripheral oedema, especially involving the fingers [18]. It is also not recommended to be used in children below 4 years of age [19]. Analyses by Wagner et al. [20] comparing CO measurements using the CNAP monitor versus transpulmonary thermodilution show an acceptable agreement in most clinical situations, and thus it may be claimed these devices may be successfully used also in critically ill patients [20]. Measurement of 


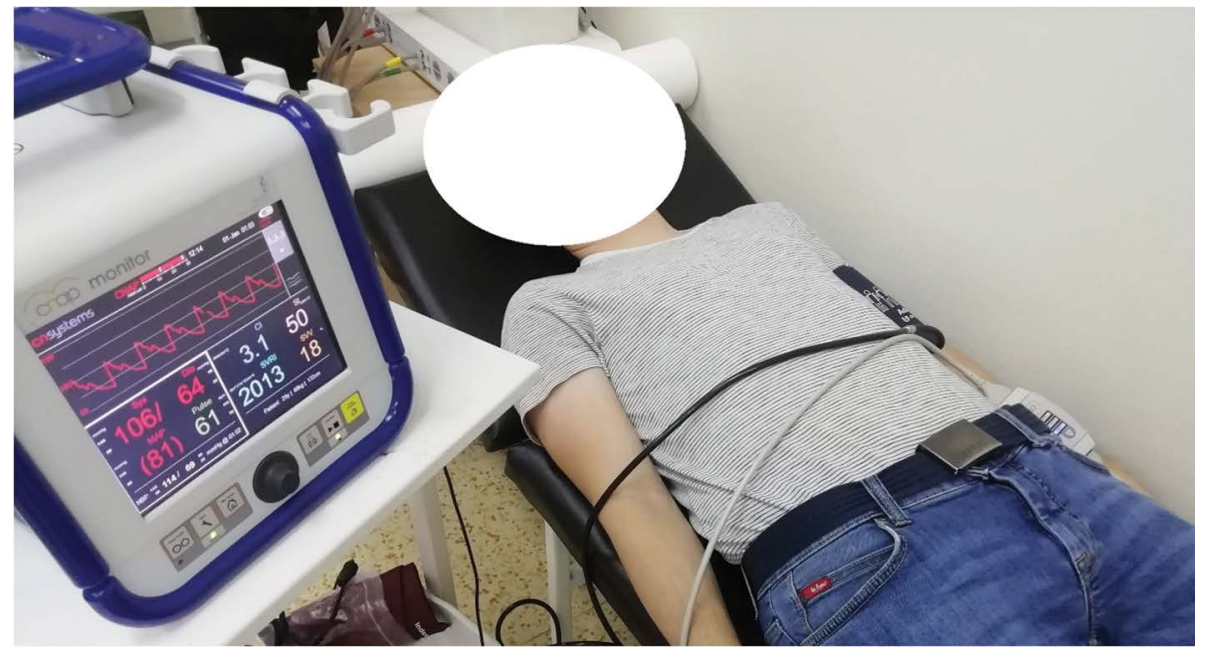

Figure 2. Assessment of haemodynamic parameters using the CNAP (continuous noninvasive blood pressure monitoring) monitor

haemodynamic parameters using the CNAP monitor is shown in Figure 2.

\section{Transthoracic echocardiography}

Echocardiographic measurement of $\mathrm{CO}$ requires imaging in two views: the apical five-chamber view and the long-axis parasternal view. In the five-chamber view, pulsed wave Doppler volume is placed below the aortic valve leaflets and the aortic flow envelope is obtained to provide the velocity time integral (VTI), while the diameter of the left ventricular outflow tract just below the aortic valve is measured in the long-axis parasternal view [21].

To calculate $\mathrm{CO}$, these readings are entered into the following formula:

\section{$\mathrm{CO}=\mathrm{VTI} \times \mathrm{S} \times \mathrm{HR}=\mathrm{VTI} \times \pi(\mathbf{1} / \mathbf{2 d}) 2$}

where $\mathrm{CO}$ - cardiac output, VTI - velocity time integral, $\mathrm{S}$ - aortic valve orifice area, HR - heart rate, and $\mathrm{d}$ - left ventricular outflow tract diameter.

A disadvantage of the method is a subjective nature of this assessment, dependent on the echocardiographer's experience, leading to low reproducibility. In contrast, a major advantage is wide availability of the echocardiographic equipment, not only in cardiology and intensive care units but also emergency departments and general internal medicine units.

\section{Use - when and in whom?}

According to some authors, non-invasive CO measurements techniques should be considered in the perioperative period in patients undergoing non-cardiac surgery, taking into account individual patient- and procedure-related risk factors. In patients undergoing open heart surgery, it is recommended to use invasive and minimally invasive monitoring methods (most commonly pulmonary artery catheterization or transoesophageal Doppler) [6]. In contrast, it seems that noninvasive techniques are a good solution for patients undergoing low and moderate risk procedures, and those which were previously deemed as not requiring intensive haemodynamic monitoring (such as procedures performed under local anaesthesia or peripheral nerve blockades) [22]. Clinical usefulness of the CNAP 500 monitor was shown, among others, for bariatric surgery in adults and paediatric patients with body weight in the range of 20-40 kg [23]. In addition, this approach seems optimal in patients with difficult radial artery cannulation, positive Allen test, and in patients undergoing vascular surgery with limited availability of vessel cannulation [24]. As noted, non-invasive are also useful during cardiac investigations such as exercise testing [25]. In addition, non-invasive monitoring may be optimal solution during patient transport, serving as a bridge tool for patient monitoring between the original location of a medical event and an intensive care unit [26].

\section{Summary}

Noninvasive CO measurement techniques are of major importance in the current medical practice, and their role may be expected to increase in the future. Multiple studies showed that with monitoring and optimizing $\mathrm{CO}$, the length of stay in intensive care units may be reduced [27, 28]. More comprehensive studies are necessary for further development of the noninvasive monitoring methods and their introduction in various clinical settings. Based on the available literature, it seems that $\mathrm{CO}$ is a parameter that has an important add-on value in the evaluation of the cardiovascular status. Another research goal should to be to identify patient groups that would benefit the most from the evaluation of this parameter. The feasibility of 
such studies is increased by the availability of non-invasive methods that eliminate the risks associated with the use of invasive methods, such as those related to large vessel catheterization.

\section{Conflict of interests}

The authors declare no conflicts of interests.

\section{References}

1. McGuinness S, Parke R. Using cardiac output monitoring to guide perioperative haemodynamic therapy. Curr Opin Crit Care. 2015; 21(4): 364-368, doi: 10.1097/MCC.0000000000000212, indexed in Pubmed: 26103145

2. Ponikowski P, Voors AA, Anker SD, et al. Grupa Robocza Europejskiego Towarzystwa Kardiologicznego (ESC) do spraw diagnostyki i leczenia ostrej i przewlekłej niewydolności serca. Dokument opracowano przy szczególnym udziale Heart Failure Association (HFA) ESC. Wytyczne ESC dotyczące diagnostyki i leczenia ostrej i przewlekłej niewydolności serca w 2016 roku. Kardiol Pol. 2016; 74(10): 1051-1052, doi: 10.5603/KP.2016.0141.

3. Elliott PM, Anastasakis A, Borger MA, et al. Grupa Robocza Europejskiego Towarzystwa Kardiologicznego (ESC) do spraw rozpoznawania i postępowania w kardiomiopatii przerostowej. Wytyczne ESC dotyczące rozpoznawania i postępowania w kardiomiopatii przerostowej w 2014 roku. Kardiol Pol. 2014; 72(11): 1091, doi: 10.5603/ /KP.2014.0212.

4. Regitz-Zagrosek V, Roos-Hesselink JW, Bauersachs J, et al. Grupa Robocza Europejskiego Towarzystwa Kardiologicznego ds. postępowania w chorobach układu sercowo-naczyniowego podczas ciąży. Wytyczne ESC dotyczące postępowaniaw chorobach układu sercowo-naczyniowego podczas ciąży (2018). Kardiol Pol. 2019; 78(3): 253-254, doi: 10.5603/KP.2019.0049.

5. Vincent JL. Understanding cardiac output. Crit Care. 2008; 12(4): 174-172, doi: 10.1186/cc6975, indexed in Pubmed: 18771592.

6. Saugel B, Vincent JL. Cardiac output monitoring. Curr Opin Crit Care. 2018; 24(3): 165-172, doi: 10.1097/mcc.0000000000000492.

7. Sangkum L, Liu GL, Yu L, et al. Minimally invasive or noninvasive cardiac output measurement: an update. J Anesth. 2016; 30(3): 461-480, doi: 10.1007/s00540-016-2154-9, indexed in Pubmed: 26961819.

8. Saugel B, Cecconi M, Wagner JY, et al. Noninvasive continuous cardiac output monitoring in perioperative and intensive care medicine. Br J Anaesth. 2015; 114(4): 562-575, doi: 10.1093/bja/aeu447, indexed in Pubmed: 25596280.

9. Kubicek WG, Karnegis JN, Patterson RP, et al. Development and evaluation of an impedance cardiac output system. Aerosp Med. 1966; 37(12): 1208-1212, indexed in Pubmed: 5339656.

10. Bernstein DP. A new stroke volume equation for thoracic electrical bioimpedance: theory and rationale. Crit Care Med. 1986; 14(10): 904-909, doi: 10.1097/00003246-198610000-00017, indexed in Pubmed: 3757533.

11. Żuchowski B, Guzik P. Elektryczna bioimpedancja klatki piersiowej. Anestezjologia i Ratownictwo. 2008; 2: 434-442.

12. Guzik P, Bychowiec B, Wysocki H. Nieinwazyjna ocena układu krążenia z wykorzystaniem elektrycznej bioimpedancji klatki piersiowej. Forum Kardiologów. 2003; 8(1): 29-33.

13. Strobeck JE, Silver MA. Beyond the four quadrants: the critical and emerging role of impedance cardiography in heart failure. Congest Heart Fail. 2004; 10(2 Suppl 2): 1-6, doi: 10.1111/j.15275299.2004.03405.x, indexed in Pubmed: 15073477.
14. Piotrowicz R, Krzesiński P, Balsam P, et al. Rozwiązania telemedyczne w kardiologii - opinia ekspertów Komisji Informatyki i Telemedycyny Polskiego Towarzystwa Kardiologicznego, Sekcji Elektrokardiologii Nieinwazyjnej i Telemedycyny Polskiego Towarzystwa Kardiologicznego oraz Komitetu Nauk Klinicznych Polskiej Akademii Nauk. Kardiol Pol. 2018; 76(3): 698-707, doi: 10.5603/KP.a2018.0058.

15. Young BP, Low LL. Noninvasive monitoring cardiac output using partial CO(2) rebreathing. Crit Care Clin. 2010; 26(2): 383-92, table of contents, doi: 10.1016/j.ccc.2009.12.002, indexed in Pubmed: 20381727.

16. Thiele RH, Bartels K, Gan TJ. Cardiac output monitoring: a contemporary assessment and review. Crit Care Med. 2015; 43(1): 177-185, doi: 10.1097/CCM.0000000000000608, indexed in Pubmed: 25251758.

17. Fortin J, Wellisch A, Maier K. CNAP - eolution of continuous non-invasive arterial blood pressure monitoring. Biomed Tech (Berl). 2013; 58(Suppl 1), doi: 10.1515/bmt-2013-4179, indexed in Pubmed: 24042825.

18. Ameloot K, Palmers PJ, Malbrain ML. The accuracy of noninvasive cardiac output and pressure measurements with finger cuff: a concise review. Curr Opin Crit Care. 2015; 21(3): 232-239, doi: 10.1097/ /MCC.0000000000000198, indexed in Pubmed: 25922896.

19. Podręcznik użytkownika CNAP Monitor 500. 2008.

20. Wagner JY, Grond J, Fortin J, et al. Continuous noninvasive cardiac output determination using the CNAP system: evaluation of a cardiac output algorithm for the analysis of volume clamp method-derived pulse contour. J Clin Monit Comput. 2016; 30(4): 487-493, doi: 10.1007/ /s10877-015-9744-1, indexed in Pubmed: 26227161.

21. Lipiec P, Hoffmann P. ed. Echokardiografia kliniczna. Podręcznik sekcji Polskiego Towarzystwa Kardiologicznego. i-medica, Warszawa 2017: 35-36.

22. Nicklas JY, Saugel B. Non-invasive hemodynamic monitoring for hemodynamic management in perioperative medicine. Front Med (Lausanne). 2017; 4: 209, doi: 10.3389/fmed.2017.00209, indexed in Pubmed: 29218310.

23. Tobias JD, McKee C, Herz D, et al. Accuracy of the CNAPTM monitor, a noninvasive continuous blood pressure device, in providing beatto-beat blood pressure measurements during bariatric surgery in severely obese adolescents and young adults. J Anesth. 2014; 28(6): 861-865, doi: 10.1007/s00540-014-1835-5, indexed in Pubmed: 24789660.

24. Kumar GA, Jagadeesh AM, Singh NG, et al. Evaluation of continuous non-invasive arterial pressure monitoring during induction of general anaesthesia in patients undergoing cardiac surgery. Indian J Anaesth. 2015; 59(1): 21-25, doi: 10.4103/0019-5049.149444, indexed in Pubmed: 25684809.

25. Vignati C, Cattadori G. Measuring cardiac output during cardiopulmonary exercise testing. Ann Am Thorac Soc. 2017; 14(Suppl_1): S48-S52, doi: 10.1513/AnnalsATS.201611-852FR, indexed in Pubmed: 28441030.

26. van Heerden PV, Baker S, Lim SI, et al. Clinical evaluation of the non-invasive cardiac output (NICO) monitor in the intensive care unit. Anaesth Intensive Care. 2000; 28(4): 427-430, doi: 10.1177/0310057X0002800412, indexed in Pubmed: 10969371.

27. Pearse R, Dawson D, Fawcett J, et al. Early goal-directed therapy after major surgery reduces complications and duration of hospital stay. A randomised, controlled trial [ISRCTN38797445]. Crit Care. 2005; 9(6): R687-R693, doi: 10.1186/cc3887, indexed in Pubmed: 16356219 .

28. Rhodes A, Cecconi M, Hamilton M, et al. Goal-directed therapy in high-risk surgical patients: a 15-year follow-up study. Intensive Care Med. 2010; 36(8): 1327-1332, doi: 10.1007/s00134-010-1869-6, indexed in Pubmed: 20376431. 